\title{
VASCULAR PLANTS OF ŁEMPIS NATURE RESERVE IN THE AUGUSTÓW FOREST (NE POLAND)
}

\author{
Pawee Pawlikowski, Iwona Dembicz, Michą Tyszkowski, Justyna Ryniewicz, Łukasz Kozub, \\ Marta Czarnocka-Cieciura, Piotr Borzeński, Wojciech Kasprzak, Magdalena Galus, \\ KRZYSZTOF FIEDOROWICZ
}

P. Borzeński, Olecko Forest Inspectorate, Kościuszki 32, 19-400 Olecko, Poland, e-mail: piotr.borzenski@gmail.com

M. Czarnocka-Cieciura, Wetland Conservation Centre association, Żwirki i Wigury 101, 02-096 Warsaw, Poland, e-mail: martaczc@gmail.com

I. Dembicz, Department of Plant Ecology and Environmental Conservation, Institute of Botany, Faculty of Biology, Biological and Chemical Research Centre, University of Warsaw and Wetland Conservation Centre association, Żwirki i Wigury 101, 02-096 Warsaw, Poland, e-mail: i.dembicz@biol.uw.edu.pl

K. Fiedorowicz, Pomorze Forest Inspectorate, Pomorze 8, 16-506 Giby, Poland, e-mail: fkrzys64@poczta.onet.pl

M. Galus, Wetland Conservation Centre association, Żwirki i Wigury 101, 02-096 Warsaw, Poland, e-mail: m.galus@bagna.pl

W. Kasprzak, Institute of English Studies, University of Warsaw, Hoża 69, 00-681 Warsaw, Poland and Wetland Conservation Centre association, Żwirki i Wigury 101, 02-096 Warsaw, Poland, e-mail: wojtekkasprzak@gmail.com

Ł. Kozub, Department of Plant Ecology and Environmental Conservation, Institute of Botany, Faculty of Biology, Biological and Chemical Research Centre, University of Warsaw and Wetland Conservation Centre association, Żwirki i Wigury 101, 02-096 Warsaw, Poland, e-mail: lukasz.kozub@biol.uw.edu.pl

P. Pawlikowski, Department of Plant Ecology and Environmental Conservation, Institute of Botany, Faculty of Biology, Biological and Chemical Research Centre, University of Warsaw and Wetland Conservation Centre association, Żwirki i Wigury 101, 02-096 Warsaw, Poland, e-mail: p.pawlikowski@uw.edu.pl

J. Ryniewicz, Botanical Garden, Faculty of Biology, University of Warsaw, Al. Ujazdowskie 4, 00-478 Warsaw and Wetland Conservation Centre association, Żwirki i Wigury 101, 02-096 Warsaw, Poland, e-mail: j.ryniewicz@biol.uw.edu.pl

M. Tyszkowski, Wetland Conservation Centre association, Żwirki i Wigury 101, 02-096 Warsaw, Poland, e-mail: michal.tyszkowski@cmlocalization.eu

(Received: November 21, 2017. Accepted: December 12, 2017)

Aвstract. During the survey of Łempis Nature Reserve (Augustów Forest, NE Poland) 353 species of vascular plants were recorded, including 32 considered threatened with extinction in Poland (7 species from the Polish "red data book" and 32 species from the Polish "red list"). Among them there were 41 species protected under the Polish law, including 19 strictly protected species and four species listed in the Annex II of the EU Habitats Directive. Ten orchid species were recorded, including the most valuable plants of the nature reserve - Cypripedium calceolus, Hammarbya paludosa, Liparis loeselii and Listera cordata. Among 32 noted Cyperaceae species (including 26 members of the Carex genus), there was a number of threatened plants, e.g. Baeothryon alpinum, Carex chordorrhiza, C. loliacea and Eriophorum gracile. Other rare species included Agrimonia pilosa, Cladium mariscus, Laserpitium latifolium, Linnaea borealis, Potamogeton gramineus and Pulsatilla patens. The presence of anthropophytes was significant ( $4.5 \%$ of the flora), probably due to the past forest management practices as well as proximity of settlements. The extremely rich flora, along with pristine wetland ecosystems (mesotrophic lakes, various mire forests and fens), places the Łempis Nature Reserve among the most valuable nature reserves in Poland.

KeY WORDS: red list species, neophytes, ancient forest species, wetland, Cyperaceae, Orchidaceae 


\section{INTRODUCTION}

The Łempis Nature Reserve was established in 1983 to preserve natural forest, as well as aquatic and mire ecosystems. The reserve covers an area of 132.21 hectares and it is located in the northern part of the Augustów Forest, in the Pomorze Forest District and the commune of Sejny, in the marginal part of the sandy outwash plain within the so-called Sejny Lakeland, within the southernmost part of the mesoregion of East Suwałki Lakeland, bordering the mesoregion of Augustów Plain; both within the Lithuanian Lake District (KONDRACKI 2002). The elevation of the reserve ranges from 124 to $139 \mathrm{~m}$ a.s.l. (GeOPORTAL... 2017). The adjacent area consists of eroded terminal moraines (formed during the Vistulian glaciation), covered with outwash sands (Sокоєоwsкi 2010). The climate of the area is humid continental with warm summer according to KöPPEN (1936). The mean annual temperature is $6.4^{\circ} \mathrm{C}$ with the average of July $16.9^{\circ} \mathrm{C}$ and of January $-5.3^{\circ} \mathrm{C}$. The mean annual precipitation averages $588 \mathrm{~mm}$ (DANE O KLIMACIE... 2017). The Łempis Nature Reserve is situated in the north-western quarter of the square GB12 in the grid cartogram of the Atlas of distribution of vascular plants in Poland (ZAJĄC 1978).

The relief of the reserve is very diverse (Fig. 1). The axis of the reserve and its heart consist of a

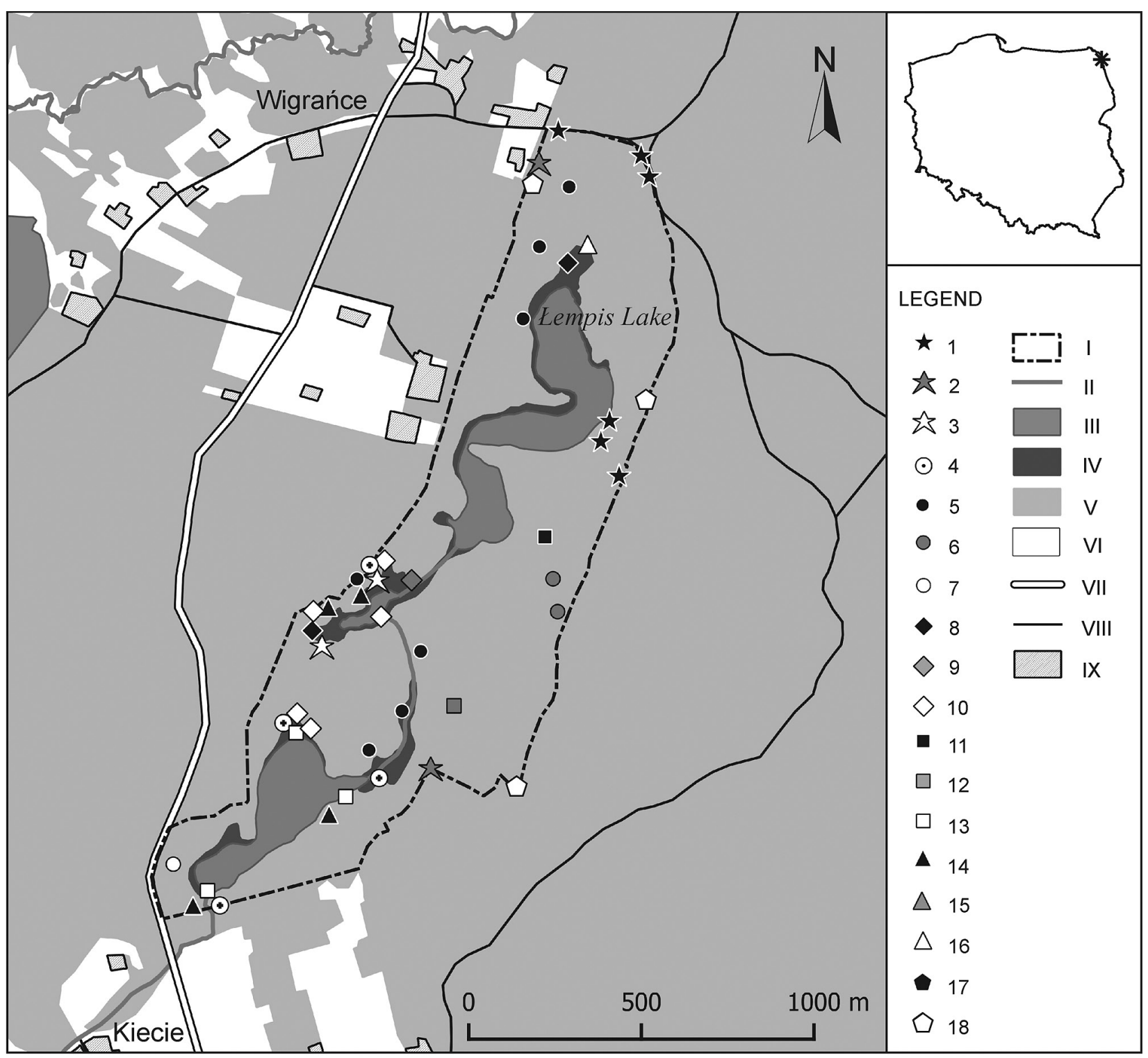

Fig. 1. Distribution of endangered plant species in the Łempis Nature Reserve. I - nature reserve boundaries, II - watercourses; III - lakes, IV - open mires, V - woodland, VI - farmland, VII - main road, VIII - dirt roads, IX - buildings; 1 - Agrimonia pilosa, 2 - Arctostaphylos uva-ursi, 3 - Baeothryon alpinum, 4 - Carex chordorrhiza, 5 - C. loliacea, 6 - Cypripedium calceolus, 7 - Diphasiastrum complanatum, 8 - Epipactis palustris, 9 - Eriophorum gracile, 10 - Hammarbya paludosa, 11 - Laserpitium latifolium, 12 - Linnaea borealis, 13 - Liparis loeselii, 14 - Listera cordata, 15 - Lycopodium clavatum, 16 - Parnassia palustris, 17 - Potentilla anglica, 18 - Pulsatilla patens 
deep (lying $10 \mathrm{~m}$ below the adjacent areas), elongated, longitudinally situated depression with a chain of three shallow (average depth 1.3-2.4 m) ribbon lakes - Łempis (12.26 ha), Stulpieniuk (other name Łemtupis, $0.6 \mathrm{ha}$ ) and Stulpień (7.40 ha); the southern part of the Łempis Lake is often considered a separate lake - Łempiuk (known also as Łempniak; $3.60 \mathrm{ha})$ (Pawlikowski 2010b). Hydrochemical evidence provided by TomAszewicz \& KŁOsowsKi (1985) and KŁosowski (1986-1987) for the Cladietum marisci association in all the three lakes showed that they are oligo- or mesotrophic, circumneutral lakes with calcareous gyttja deposits. Remaining part of the depression is covered with peat originating from diverse types of peatlands - rich fens, poor fens and bogs (peat identified with the help of boreholes; P. Pawlikowski 2003-2015 unpubl.). Lakes and peatland constitute together ca $50 \%$ of the reserve area. Adjacent mineral areas are covered predominantly with various subtypes of arenosol soils $(38 \%$ of the reserve area, including more fertile brunic arenosols $-4.5 \%$ ) and (mostly gleic-) podzols (6\%) (SoкоŁowSKI 2010).

Vegetation of the reserve reflects diverse environmental conditions. Submerged aquatic vegetation of the reserve is poorly developed and consists of just a few species. The littoral zone is covered with Cladietum marisci, Thelypteridi-Phragmitetum and Phragmitetum communis associations and borders either pristine open or sparsely forested fen vegetation (below 5\% of the reserve area) or very well preserved peatland woodlands (nearly $40 \%$ ), mainly pine-birch swamp forests (Betula pubescens-Thelypteris palustris community). Other mire forest types include bog woodlands Vaccinio uliginosi-Pinetum, alder carrs resembling $\mathrm{Ca}$ rici elongatae-Alnetum and spruce-dominated forests on peat including small patches of the Sphagno girgensohnii-Piceetum association. The marginal zone of peatlands is often occupied by moist mixed forest Querco-Piceetum or (in the northern part) small patches of wet forests of the Alno-Ulmion alliance dominated by alder and spruce. Around the depression, forests on purely mineral soils (ca 40\%) are dominated by pine and spruce of usually uniform age and resemble predominantly typical managed forests. In the northernmost part of the reserve the coniferous stands of a secondary origin and are slowly being replaced by vegetation typical of the decidous TilioCarpinetum association, while in some other parts of the reserve patches of typical mesic-dry pine forests of the Peucedano-Pinetum association are present (Pawlikowski 2010b, P. Pawlikowski 2003-2015 unpubl.). Some parts of the Sphagnum- and pine-dominated sparse woodlands have been regarded as ombrotrophic (raised) bogs by SoкоŁowski (2010).

Vascular plants of the Łempis Nature Reserve have not been the subject of a separate publication yet. According to Sокоєоwsкi (2010), in the 1970s within the area of the present reserve 170 species of vascular plants were noted, of which only 50 were listed in the cited publication. Aquatic and mire vegetation of the present nature reserve has been a subject of surveys by botanists from the University of Warsaw (Institute of Botany) since the late 1970s. Published materials include the locality of Cladium mariscus (KŁosowski \& Tomaszewicz 1979) and the Cladietum marisci association (KŁOsowski 1986-1987), aquatic and reed-bed vegetation (Tomaszewicz \& KŁosowsKi 1985), the locality of Baeothryon alpinum (PawLIKowSKI 2010a) and mire vegetation of the reserve (PAWLIKOWSKI 2010b). The total of 86 vascular plant species have been listed in the above publications, including 35 species protected under the present law (RozPORZADZENIE... 2014) and 21 threatened species according to the new Polish "red list" (Kaźmierczakowa et al. 2016) and "red data book" (KaźmierczaKowa et al. 2014).

The aim of the study was to complete the list of vascular plants of the Łempis Nature Reserve in the Augustów Forest and determine the conservation status of rare and endangered species there as well as assess the naturalness of the reserve's flora.

\section{MATERIALS AND METHODS}

The present survey of vascular plants of the Łempis Nature Reserve was carried out mainly in July 2014, with supplementing inventories in April, August and September 2014 and July 2015. A number of previous rare species records from the years 1988-2015 (K. Fiedorowicz unpubl.) and 2002-2013 (P. Pawlikowski unpubl.) have been verified during the present survey.

The study was conducted using the topographic method (FALIŃsKi 1990). The names of vascular plant species and their status as anthropophytes follow Mirek et al. (2002). The list of species contains the following additional information:

- category of threat according to the "Polish plant red data book" (KAźmierczAKowa et al. 2014: CR - critically endangered species, EN - endangered species, VU - vulnerable species)

- category of threat according to the "Polish red list of pteridophytes and flowering plants" (KAŹMIERCZAKOWA et al. 2016): [EN] - endangered species, [VU] - vulnerable species, $[\mathrm{NT}]$ - near threatened species

- species listed in the Annex II of the UE Habitats Directive (HD)

- information on protection status in Poland according to ROZPORZĄDZENIE... (2014) (S - strictly protected species, $\mathrm{P}$ - partially protected species)

- information on the 'ancient forest species' according to DzWonko \& Loster (2001) (AF)

- information on the anthropophyte status according to MireK et al. (2002) (A) 
- information on the occurrence exclusively or almost exclusively in non-forest habitats (o - exclusively open mire and aquatic habitats, (o) - almost exclusively open mire and aquatic habitats, a - exclusively anthropogenic habitats (paths, roadsides, clearings), (a) - almost exclusively anthropogenic habitats)

- layer in which the tree and shrub species have been present $\left(a_{1}\right.$ - upper tree layer, $a_{2}$ - lower tree layer, $\mathrm{b}$ - shrub layer, between 1.5 and 5 meters of height, $c$ - herbs layer)

- relative abundance of a species in the reserve: 1 - very scarce (up to several shoots or even numerous but over the area not exceeding several square metres), 2 - scarce (dozens of shoots or even numerous but over the area of $10-100 \mathrm{~m}^{2}$ ), 3 - moderately abundant (hundreds of shoots over the area of more than $100 \mathrm{~m}^{2}$ ), 4 - numerous (thousands of shoots), 5 - very numerous (dozens of thousands of shoots), 6 - dominant or co-dominant (covering more than $10 \%$ of the area).

The distribution of most valuable species, their distribution and population size are further discussed in the results section.

\section{RESULTS}

The flora of the reserve consisted of 353 species of vascular plants, including 232 dicots, 99 monocots, four gymnosperms and 18 species of pteridophytes. Among them were 23 species threatened with extinction in Poland, including seven included in the "Polish red data book" (KAŹMIERCZAKOWA et al. 2014): Baeothryon alpinum, Carex chordorrhiza, Cypripedium calceolus, Eriophorum gracile, Hammarbya paludosa, Liparis loeselii and Pulsatilla patens. There were 32 taxa listed in the "Polish red list of pteridophytes and flowering plants" (KAŹMIERCZAKOWA et al. 2016); apart from those mentioned above there were: Agrimonia pilosa, Arctostaphylos uva-ursi, Carex diandra, C. dioica, C. limosa, C. loliacea, Chimaphila umbellata, Cladium mariscus, Dactylorhiza incarnata, Drosera rotundifolia, Epipactis palustris, Goodyera repens, Huperzia selago, Linnaea borealis, Listera cordata, Najas marina, Parnassia palustris, Potamogeton gramineus, Rhynchospora alba, Salix myrsinifolia, Scheuchzeria palustris, Sparganium minimum, Utricularia intermedia, $U$. minor and $U$. vulgaris. The total of 41 species under legal protection in Poland were found, including 18 strictly protected species and four species listed in the Annex II of the UE Habitats Directive. Within the reserve, as much as 16 alien species were recorded, including eight species of trees and shrubs, resulting from forest management. Quercus rubra is the only alien species abundant in the reserve. While the flora of the reserve includes 59 ancient forest species, 71 species were found exclusively in non-forest vegetation, including 23 species present only in natural (mire and aquatic) communities and 67 species bound to anthropogenic habitats, mainly roads and forest paths.

\section{LIST OF SPECIES}

Species are listed in alphabetical order within the classes. Additional information is given in brackets (for details see Materials and methods section).

Equisetopsida: Equisetum arvense (a, 1), E. fluviatile (4), E. hyemale (1), E. pratense (a, 2), E. sylvaticum (AF, 4).

Lycopodiopsida: Diphasiastrum complanatum (P, 1), Huperzia selago ([NT], P, AF, 3), Lycopodium annotinum (P, AF, 6), L. clavatum (P, 1).

Polypodiopsida: Athyrium filix-femina (AF, 4), Dryopteris carthusiana (AF, 4), D. cristata (AF, 3), D. dilatata (AF, 3), D. filix-mas (AF, 3), Gymnocarpium dryopteris (AF, 3), Phegopteris connectilis (AF, 2), Pteridium aquilinum (AF, 4), Thelypteris palustris (6).

Pinopsida: Juniperus communis (b,c, 4), Larix cfr. decidua (A, $\left.\mathrm{a}_{2}, \mathrm{~b}, \mathrm{c}, 2\right)$, Picea abies $\left(\mathrm{a}_{1}, \mathrm{a}_{2}, \mathrm{~b}, \mathrm{c}, 6\right)$, Pinus sylvestris $\left(\mathrm{a}_{1}, \mathrm{a}_{2}, \mathrm{~b}, \mathrm{c}, 6\right)$.

Magnoliopsida: Acer platanoides (b,c, 2), A. pseudoplatanus (A, b,c, 2), Achillea millefolium (1), Acinos arvensis (a, 2), Actaea spicata (AF, 2), Aegopodium podagraria (AF, 2), Agrimonia eupatoria (a, 2), A. pilosa ([NT], $\mathrm{HD}, \mathrm{S}, \mathrm{a}, 2)$, Ajuga reptans (AF, 2), Alchemilla glabra (a, 2), Alnus glutinosa ( $\left.\mathrm{a}_{1}, \mathrm{a}_{2}, \mathrm{~b}, \mathrm{c}, 5\right)$, Andromeda polifolia (P, 5), Anemone nemorosa (AF, 4), Angelica sylvestris (2), Anthriscus sylvestris (a, 2), Aquilegia vulgaris (P, 1), Arctium nemorosum (a, 1), Arctostaphylos uva-ursi ([NT], S, (a), 2), Artemisia vulgaris (a, 1), Asarum europaeum (AF, 2), Astragalus arenarius ((a), 2), A. glycyphyllos (1), Betula pendula $\left(\mathrm{a}_{1}, \mathrm{a}_{2}, \mathrm{~b}, \mathrm{c}, 3\right)$, B. pubescens $\left(\mathrm{a}_{1}, \mathrm{a}_{2}, \mathrm{~b}, \mathrm{c}, 5\right)$, Callitriche sp. (4), Calluna vulgaris (4), Caltha palustris (4), Campanula patula (a, 2), C. persicifolia (2), C. rapunculoides (2), C. rotundifolia (a, 2), Capsella bursa-pastoris (A, a, 2), Cardamine amara (3), C. pratensis (2), Carpinus betulus (b,c, 2), Centaurea jacea (a, 2), Cerastium holosteoides (a, 2), Cerasus avium (A, c, 1), Chaenomeles japonica (A, a, 1), Chaerophyllum aromaticum (a, 3), Chamaenerion angustifolium (3), Chelidonium majus (a, 2), Chenopodium album (a, 1), Chimaphila umbellata ([NT], P, 2), Chrysosplenium alternifolium (AF, 5), Cicuta virosa (2), Circaea alpina (AF, 5), Cirsium arvense (a, 2), C. oleraceum (3), C. palustre (3), Clinopodium vulgare (3), Comarum palustre (5), Conyza canadensis (A, a, 1), Cornus sanguinea (b,c, 2), Corylus avellana (b,c, 3), C. monogyna $(\mathrm{b}, \mathrm{c}, 1)$, Crepis paludosa (5), Daphne mezereum (P, AF, b,c, 2), Drosera rotundifolia ([NT], S, 5), Echinocystis lobata (A, (a), 1), Empetrum nigrum (P, 4), Epilobium montanum (AF, 2), E. palustre (2), Erigeron acris ((a), 1), Euonymus europaeus (b,c, 2), E. verrucosus (b,c, 3), Eupatorium cannabinum (2), Fallopia dumetorum (a, 2), Filipendula ulmaria (3), Fragaria vesca (5), Frangula alnus (b,c, 5), Fraxinus excelsior $\left(\mathrm{a}_{2}, \mathrm{~b}, \mathrm{c}, 1\right)$, Galeobdolon luteum (AF, 4), Galeopsis bifida (a, 2), G. pubescens (a, 1), Galium boreale (2), G. mollugo (2), G. palustre (4), 
G. uliginosum (w, 2), G. verum (a, 1), Geranium robertianum (3), G. sanguineum (3), Geum rivale (3), G. urbanum (AF, 2), Gnaphalium sylvaticum ((a), 1), Hepatica nobilis (AF, 3), Heracleum sibiricum (a, 1), Hieracium lachenalii (2), H. laevigatum (2), H. murorum (AF, 4), H. pilosella ((a), 2), H. umbellatum (3), Hypericum perforatum (3), Hypochoeris radicata (a, 2), Impatiens noli-tangere (AF, 3), I. parviflora (A, 1), Knautia arvensis (3), Laserpitium latifolium (1), Lathyrus sylvestris (1), L. vernus (AF, 2), Ledum palustre (P, 5), Leontodon autumnalis (a, 2), Leucanthemum vulgare (2), Linaria vulgaris ((a), 2), Linnaea borealis ([VU], P, 2), Lonicera periclymenum (P, A, c, 1), L. xylosteum (b,c, 2), Lupinus polyphyllus (A, a, 2), Lychnis flos-cuculi ((w), 2), Lycopus europaeus (3), Lysimachia thyrsiflora (4), L. vulgaris (5), Lythrum salicaria (2), Malus sylvestris ( $\left.\mathrm{a}_{2}, \mathrm{~b}, \mathrm{c}, 2\right)$, Medicago falcata (a, 2), $M$. lupulina ( $\mathrm{a}, 1)$, Melampyrum nemorosum (AF, a, 1), $M$. pratense (AF, 4) Mentha arvensis (a, 2), Menyanthes trifoliata (P, 5), Mercurialis perennis (AF, 3), Moehringia trinervia (AF, 4), Monotropa hypopitys (2), Mycelis muralis (AF, 3), Myosotis palustris (2), Myosoton aquaticum (1), Myriophyllum verticillatum (w, 2), Nuphar lutea (w, 3), Nymphea alba (P, w, 3), Oenothera biennis (A, a, 1), Orthilia secunda (AF, 4), Oxalis acetosella (AF, 5), Oxycoccus palustris (6), Padus avium ( $\left.\mathrm{a}_{2}, \mathrm{~b}, \mathrm{c}, 3\right)$, Padus serotina (A, c, 1), Parnassia palustris ([VU], (w), 1), Parthenocissus inserta (A, (a), 2), Peucedanum oreoselinum (3), P. palustre (4), Physocarpus opulifolius (A, a, 1), Pimpinella saxifraga (3), Plantago lanceolata (a, 2), P. major (a, 2), P. media $(\mathrm{a}, 1)$, Polygala vulgaris (a, 1), Polygonum aviculare $(\mathrm{a}, 2)$, P. mite (3), Populus tremula $\left(\mathrm{a}_{2}, \mathrm{~b}, \mathrm{c}, 3\right)$, Potentilla anglica $(\mathrm{a}, 2)$, . arenaria $((\mathrm{a}), 2)$, P. argentea $(\mathrm{a}, 2)$, P. erecta $(4)$, $P$. reptans $(\mathrm{a}, 2)$, Prunella vulgaris $(\mathrm{a}, 3)$, Prunus cerasifera (A, $\left.\mathrm{a}_{2}, \mathrm{~b}, \mathrm{c}, 1\right)$, Pulsatilla patens (EN, [EN], HD, S, (a), 1), Pyrola chlorantha (P, 2), P. minor (P, 2), P. rotundifolia (P, 2), Pyrus pyraster (A, b,c, 2), Quercus robur (a,b,c, 3), Q. rubra (A, a, b,c, 4), Ranunculus acris (a, 2), $R$. flammula (4), R. lingua (3), R. repens (3), Rhamnus catharticus (b,c, 2), Ribes alpinum (1), R. nigrum (AF, 3), $R$. spicatum (AF, 2), Rubus idaeus (3), R. plicatus (3), $R$. saxatilis (4), Rumex acetosa ((w), 1), $R$. acetosella (2), $R$. obtusifolius $(\mathrm{a}, 1), \mathrm{R}$. thyrsiflorus $(\mathrm{a}, 2)$, Salix aurita (3), S. caprea $\left(\mathrm{a}_{2}, \mathrm{~b}, \mathrm{c}, 2\right), \mathrm{S}$. cinerea (5), S. fragilis $(\mathrm{a}, 1), \mathrm{S}$. myrsinifolia ([NT], w, 1), S. pentandra (2), S. rosmarinifolia (3), Sarothamnus scoparius (A, 2), Scleranthus perennis (a, 1), Scorzonera humilis (3), Scrophularia nodosa (AF, 3), Scutellaria galericulata (3), Senecio jacobea (a, 2), S. vulgaris $(\mathrm{a}, 1)$, Silene nutans $(2), S$. vulgaris $(\mathrm{a}, 1)$, Solanum dulcamara (3), Solidago virgaurea (AF, 3), Sorbus aucuparia (b,c, 3), Stellaria graminea (2), S. media (2), S. nemorum (AF, 3), S. uliginosa (2), Succisa pratensis (1), Taraxacum officinale $(\mathrm{a}, 2)$, Thalictrum aquilegiifolium (2), Thymus serpyllum (2), Tilia cordata (b,c, 2), Torilis japonica (a, 2), Trientalis europaea (AF, 4), Trifolium alpestre (3), T. medium (a, 2), T. pratense (a, 2), T. repens (a, 2), Tussilago farfara (a, 1), Urtica dioica (2), Utricularia intermedia ([VU], S, w, 4), U. minor ([NT], S, w, 4), U. vulgaris ([NT], w, 5), Vaccinium myrtillus (AF, 5), V. uliginosum (4), $V$. vitis-idaea (AF, 4), Verbascum nigrum (1), Veronica beccabunga ((w), 2), V. chamaedrys (3), V. officinalis (2), Viburnum opulus (b,c, 3), Vicia cassubica (2), V. cracca (a, 2), V. sepium (a, 1), Vincetoxicum hirundinaria (2), Viola canina (2), $V$. mirabilis (AF, 3), V. palustris (5), V. riviniana (AF, 4).

Liliopsida: Agrostis canina (2), A. capillaris (2), A. stolonifera (2), Allium ursinum (P, AF, 1), Anthericum ramosum (3), Anthoxanthum odoratum (2), Arrhenatherum elatius (a, 2), Baeothryon alpinum (VU, [VU], P, (w), 3), Brachypodium sylvaticum (AF, 2), Briza media (2), Calamagrostis arundinacea (4), C. canescens (4), C. epigejos (2), C. stricta ((w), 2), Calla palustris (5), Carex acutiformis (6), C. appropinquata (5), C. canescens (5), C. cespitosa (3), C. chordorrhiza (VU, [VU], S, 4), C. diandra ([NT], w, 3), C. digitata (AF, 5), C. dioica ([VU], P, 5), C. echinata (5), C. elongata (AF, 5), C. ericetorum (1), C. hirta (2), C. lasiocarpa (6), C. lepidocarpa ((w), 3), C. limosa ([NT], (w), 5), C. loliacea ([VU], S, 3), C. nigra, (5), C. ovalis (2), C. pallescens (2), C. panicea ((w), 3), C. paniculata (5), C. pseudocyperus (4), C. remota (AF, 5), C. rostrata (5), C. spicata (a, 1), C. viridula (w, 1), Cladium mariscus ([NT], W, 5), Convallaria majalis (AF, 3), Cypripedium calceolus (VU, [VU], HD, S, 1), Dactylis glomerata (a, 2), Dactylorhiza fuchsii (S, AF, 3), D. incarnata ([NT], P, W, 2), D. maculata (P, (w), 3), Danthonia decumbens (2), Deschampsia caespitosa (3), D. flexuosa (3), Eleocharis palustris (w, 3), Elymus repens (a, 2), Epipactis palustris (V, S, 3), Eriophorum angustifolium (4), E. gracile (CR, [EN], S, w, 3), E. vaginatum (5), Festuca gigantea (AF, 3), F. ovina (2), F. pratensis (a, 2), F. rubra (2), Glyceria fluitans (3), Goodyera repens ([NT], S, 3), Hammarbya paludosa (EN, [EN], S, (w), 2), Holcus lanatus (a, 2), H. mollis (a, 1), Hydrocharis morsus-ranae (4), Juncus articulatus (w, 2), J. effusus (2), Lemna minor (4), Lilium martagon (S, AF, 1), Liparis loeselii (VU, [VU], HD, S, w, 2), Listera cordata ([VU], S, 2), Lolium perenne (a, 2), Luzula campestris, (1), L. pilosa (AF, 4), Maianthemum bifolium (AF, 5), Melica nutans (AF, 3), Molinia caerulea (5), Najas marina ([NT], w, 3), Neottia nidus-avis (P, AF, 2), Paris quadrifolia (AF, 3), Phleum pratense (a, 2), Phragmites australis (5), Poa angustifolia (3), P. annua (a, 2), P. pratensis (3), P. trivialis (2), Polygonatum multiflorum (AF, 2), P. odoratum (AF, 3), Potamogeton gramineus ([VU], w, 3), P. natans (w, 4), Rhynchospora alba ([NT], (w), 4), Scheuchzeria palustris ([VU], S, (w), 5), Scirpus sylvaticus (2), Sparganium emersum (2), S. minimum ([NT], 4), Triglochin palustre (w, 2), Typha latifolia (w, 3).

\section{DISTRIBUTION AND POPULATION SIZE OF THE MOST INTERESTING AND THREATENED SPECIES}

The localities of the threatened plant species were aggregated predominantly in the post-glacial depression, in open or sparsely wooded fens along the four lakes and in adjacent mire forests (Fig. 1). These 
included most important orchids (Hammarbya paludosa, Liparis loeselii) and members of the Cyperaceae family (Baeothryon alpinum, Carex chordorrhiza, Cladium mariscus, Eriophorum gracile). Mires adjacent to the lakes Stulpieniuk and Stulpien host the majority of valuable species recorded. Less important for the threatened plants are wetland coniferous forests (with the species such as Listera cordata and Carex loliacea) and remnants of xerophilous pine forests and their margins (with e.g. Pulsatilla patens and Laserpitium latifolium). There was a high diversity of orchids (10 species), most of them bound to wetlands, both open and wooded.

Populations of endangered wetland species were predominantly vital and not threatened due to stable hydrologic conditions and hardly noticeable successional processes in the reserve's mires. In contrast, the light-demanding species in pine(-spruce) forests on adjacent mineral soils seem to decline. The populations of Cypripedium calceolus, Pulsatilla patens, Laserpitium latifolium and Arctostaphylos uva-ursi are small, consisting chiefly of sterile individuals, extremely threatened due to expansion of spruce, deciduous shrubs and tall herbs and thus on the verge of extinction.

\section{DISCUSSION AND CONCLUSIONS}

An outstanding number of threatened vascular plant species recorded in the Łempis Nature Reserve (23 species) is unique and situates the reserve among most valuable nature reserves in Poland. In two other recently surveyed nature reserves in the Augustów Forest - Kozi Rynek and Mały Borek - 10 threatened species have been recorded in each (PAwLIKowski et al. 2011, 2013). The most important species of the Łempis Nature Reserve were members of the Cyperaceae family (e.g. Baeothryon alpinum, Carex chordorrhiza and Eriophorum gracile) and Orchidaceae family (e.g. Hammarbya paludosa, Liparis loeselii, Cypripedium calceolus), the majority of them connected with open mire vegetation (excluding the last mentioned species, which is bound to forests on mineral soils, but just at the mire margins).

Comparing existing data on the plant cover of the reserve from the 1970s and early 1980s (KŁosowSKI \& Tomaszewicz 1979, Tomaszewicz \& KŁosowsKI 1985, KŁosowsKi 1986-1987, Sокоџошsк 2000, 2010, $\mathrm{S}$. Kłosowski, personal communication in the years 2002-2013) with the present information, it is clear that ecological conditions and plant cover of the mire ecosystems in the reserve are stable and are not subject to intensive secondary succession processes. The only significant negative change recorded is the expansion of Phragmites australis reed-beds and decrease of Cladium mariscus stands, but mainly around the Łempis Lake; the replacement is only slightly visible in the vicinity of the remaining lakes (Stulpien and
Stulpieniuk). At the same time, forests of the reserve have been subject to significant changes: increased abundance of broadleaf species (in lower layers) and spruce (in all layers), increased cover of the herb layer cover and higher fertility, and - in the northern part of the reserve - also the development of forest floor species typical of broadleaf (oak-hornbeam) forests. The processes described have caused the vanishing of light-demanding, thermophilous species typical of open pine forests, such as Arnica montana, Prunella grandiflora and Platanthera bifolia (all three species have not been confirmed and are almost certainly extinct in the reserve). Their disappearance was accelerated by the artificial introduction of Quercus rubra, an alien species, over a large expanse of former open pine forests. The proposals to remove the harmful species (see Sокоєоwsкi 2010), have not been implemented yet. Moreover, other neophytes are encroaching, mainly from the areas adjacent to settlements in the north-western and southern part of the reserve. On the other hand, the Łempis Nature Reserve hosts populations of a large number of ancient forest species, which entails the presence of well-developed and valuable forest habitats. The number of such species noted in the surveyed reserve (59) is similar to that confirmed in two other nature reserves established in the Augustów Forest predominantly to preserve old-growth forests: Mały Borek (54) and Kozi Rynek (65) (PawLikowski et al. 2011, 2013).

Out of the vascular plant species listed by Sокоєошsкi $(2000,2010)$, except the already mentioned light-demanding species typical of pine forests on mineral soils, four species have not been presently confirmed: Dactylorhiza majalis, Drosera anglica, Listera ovata and Potamogeton perfoliatus. The reasons for their disappearance are not clear. The first species listed was last seen in the reserve in the year 2005 (Pawlikowski 2010b, P. Pawlikowski unpubl.). Dactylorhiza majalis could have been erroneously reported, since the species is very rare in north-easternmost Poland (BERNACKI 1998) and often confused with other Dactylorhiza species (especially D. baltica and some hybrids).

\section{ACKNOWLEDGEMENTS}

The survey was organised as one of the activities of the Wetland Conservation Centre association and students' Scientific Group of Environmental Conservation at the University of Warsaw. We are grateful to dr hab. Joanna Zalewska-Gałosz and Łukasz Krajewski for identifying Potamogeton gramineus. Our survey in the Łempis Nature Reserve was carried out in accordance with permissions issued by the Regional Directorate for Environmental Protection in Białystok (mainly on the basis of decision no. WPN.6250.152.2014.MW). 


\section{REFERENCES}

Bernacki L. (1998): Die Verbereitung der Arten, Unterarten und Bastarde der Orchide-engattung Dactylorhiza in Polen. Jahresberichte des Naturwissenschaftlichen Vereins in Wuppertal 51: 191212

DANE O KLIMACIE dla miast na całym świecie. https:// pl.climate-data.org/ (access: 5.01.2017).

Dzwonko Z., Loster S. (2001): Wskaźnikowe gatunki roślin starych lasów i ich znaczenie dla ochrony przyrody i kartografii roślinności. Prace Geograficzne 178: $120-132$.

FALIŃSKI J.B. (1990): Kartografia geobotaniczna. 2. Kartografia fitosocjologiczna. PPWK, WarszawaWrocław.

GeOPORTAL Infrastruktury Informacji Przestrzennej. Główny Urząd Geodezji i Kartografii. www.geoportal.gov.pl (access: 5.01.2017).

Kaźmierczakowa R., Bloch-Oreowska J., Celka Z., Cwener A., Dajdok Z., Michalska-Hejduk D., Pawlikowski P., SzczęŚniak E., Ziarnek K. (2016): Polska czerwona lista paprotników i roślin kwiatowych. Polish red list of pteridophytes and flowering plants. Instytut Ochrony Przyrody Polskiej Akademii Nauk, Kraków.

KaźMierczakowa R., ZarZYCKI K., MireK Z. (2014): Polska czerwona księga roślin. Instytut Ochrony Przyrody Polskiej Akademii Nauk, Kraków.

KŁosowski S. (1986-1987): Cladietum marisci (All. 1922) Zobrist $1935 \mathrm{w}$ północno-wschodniej Polsce na tle warunków siedliskowych. Fragmenta Floristica et Geobotanica 31-32(1-2): 207-223.

KŁosowski S., Tomaszewicz H. (1979): Rzadkie i interesujące rośliny z Pojezierza Suwalskiego. Fragmenta Floristica et Geobotanica 25(3): 371-375.

Kondracki J. (2002): Geografia regionalna Polski. Wydawnictwo Naukowe PWN, Warszawa.

KöPPEN W. (1936): Das geographische System der Klimate. In: W. Köppen, R. Geiger (eds). Handbuch der Klimatologie. Gebrüder Borntraeger, Berlin: 1-44.

Mirek Z., Pię́Koś-Mirkowa H., Zając A., Zając M. (2002): Flowering plants and pteridophytes of Poland. A checklist. Biodiversity of Poland.Vol. 1. W. Szafer Institute of Botany, Polish Academy of Sciences, Kraków.
Pawlikowski P. (2010a): Baeothryon alpinum (L.) Egor. (Cyperaceae) in the Polish Lowlands: distribution, population decrease and implications for conservation. Acta Societatis Botanicorum Poloniae 79(3): 215-223.

Pawlikowski P. (2010b): Torfowiska Pojezierza Sejneńskiego. In: A. Obidziński (ed.). Z Mazowsza na Wileńszczyznę. Zróżnicowanie i ochrona szaty roślinnej pogranicza Europy Środkowej i Północno-Wschodniej. Polskie Towarzystwo Botaniczne - Zarząd Główny, Warszawa: 358-380.

Pawlikowski P., WoŁkowycki D., Jarzombrowski F., ZAniewski P., Dembicz I., Galus M., Kozub Ł., Zarzecki R. (2011): Flora roślin naczyniowych rezerwatu Kozi Rynek w Puszczy Augustowskiej. Parki Narodowe i Rezerwaty Przyrody 30(1-2): 3-12.

Pawlikowski P., WoŁkowycki D., Zaniewski Z., Dembicz I., Torzewski K., Zarzecki R., Cąkaza A., Kotowska K., Galus M., Topolska K. (2013): Vascular plants of the Mały Borek nature reserve in the Augustów Forest (NE Poland). Botanika-Steciana 17: $61-65$.

RozPoRZĄDZENIE Ministra Środowiska z dnia 9 października 2014 r. w sprawie ochrony gatunkowej roślin. (2014). Dz.U. 2014, poz. 1409.

Sокоєоwsкi A.W. (2000): Hammarbya paludosa (Orchidaceae) w północno-wschodniej Polsce. Fragmenta Floristica et Geobotanica Polonica 7: 349-353.

Sокоєоwski A.W. (2010): Puszcza Augustowska. Centrum Informacyjne Lasów Państwowych, Warszawa.

Tomaszewicz H., KŁosowski S. (1985): Roślinność wodna i szuwarowa jezior Pojezierza Sejneńskiego. Monographiae Botanicae 67(3): 69-141.

ZAJĄC A. (1978): Atlas of distribution of vascular plants in Poland (ATPOL). Taxon 27(5-6): $481-484$.

For citation: Pawlikowski P., Dembicz I., Tyszkowski M., Ryniewicz J., Kozub Ł., Czarnocka-Cieciura M., Borzeński P., Kasprzak W., Galus M., FiedoRowicz K. (2017): Vascular plants of Łempis nature reserve in the Augustów Forest (NE Poland). Steciana 21(3): 107-113. doi: 10.12657/steciana.021.013 